\title{
Zonality of ore-forming chrome spinels of medium-chrome and aluminous chromitites of the Voikaro-Syninsky massif
}

\author{
Pavel Borisovich SHIRYAEV ${ }^{1,2^{*}}$ \\ Nadezhda Vladimirovna VAKHRUSHEVA ${ }^{1,2 * *}$
}

${ }^{1}$ The Zavaritsky Institute of Geology and Geochemistry of the Ural Branch of RAS, Ekaterinburg, Russia

${ }^{2}$ Ural State Mining University, Ekaterinburg, Russia

\begin{abstract}
Relevance of the work. The conditions for the formation of chromium ores in alpine-type ultramafites remain a topical subject of research. In recent years, scientific papers have focused on the issue of changing the chemical composition of ore-forming minerals and chromium ores under the influence of deformation and dynamic recrystallization processes accompanying metamorphism. The results of such studies make it possible to formulate a new model of the formation of chromium mineralization taking into account a significant amount of geological data indicating that alpine-type ultramafic rocks are "mantle tectonites". In our work, we have studied zonal ore-forming spinels from chrome ores of the Polar Urals. The results of the study make it possible to associate the formation of chemical zoning in minerals and ore bodies with recrystallization under the influence of stress tension.

Purpose of the work - study of the conditions for the formation of chemical zoning of chromium spinels from alumina and medium chromium ores of the Voikaro-Syninsky massif.

Results. Zonal ore-forming spinels from medium-chromium and aluminous chromitites of the Voikaro-Syninsky massif (Polar Urals) have been studied. It was found that replacement rims are developed along the grains of oreforming spinels with an increased content of $\mathrm{Cr}_{2} \mathrm{O}_{3}$ and an oxidation state of iron in relation to the core, as well as a reduced content of $\mathrm{Al}_{2} \mathrm{O}_{3}$. The oxidation state of iron in the rims of most grains does not exceed the values typical for unaltered ore-forming spinels. $\mathrm{T}-\mathrm{fO}_{2}$ parameters of zoning formation in spinels were determined by oxythermobarometry. Comparison with zoned chrome spinels of the Golyamo Kamenyane massif (Bulgaria).

Conclusion. Metamorphic transformations of alumina and medium-chromium chromitites of the Voikaro-Syninsky massif, occurring under subcrustal conditions under the action of directional stress at relatively constant $\mathrm{T}-\mathrm{fO}_{2}$ parameters, lead to an increase in the chromium content of the ore mineral.
\end{abstract}

Keywords: Polar Urals, chromium ores, chemical zoning, dynamic recrystallization, stress, strain.

Introduction

The zoning of ore-forming and accessory chrome spinels from alpine-type ultramafic rocks is the subject of numerous studies. It is formed because of metamorphic transformations of rocks and chromium ores [1-5]; under the influence of directed stress [6,7]; because of the redistribution of iron and magnesium between spinel and olivine when the temperature changes $[8,9]$.

Previously, we studied the chemical zoning of chromium spinels and olivines from high-chromium chromitites and ore-bearing rocks of the Tsentralnoye deposit and medium-chromium chromitites of the Yengayskoe-1 ore occurrence in the Rai-Iz massif $[10,11]$. It was found that the chemical zoning of spinels is formed under conditions of a decrease in temperature and an increase in oxygen fugacity. The amount of aluminum oxide decreases to the edges of the grains of the mineral; the iron content and the degree of oxidation of iron increase. The $\mathrm{Cr}_{2} \mathrm{O}_{3}$ content in spinels from the ores of the Tsentralnoye deposit and the Yengayskoye-1 ore occurrence varies from the centre to the edge of the grain in different ways: in the first case, it increases, in the second - decreases. This may be due to the different pressures at which the zoning of the mineral was formed. The ore-hosting meta-ultramafic rocks, amphibole-enstatite-olivine rocks, contain elongated spinel grains with asymmetric zoning in $\mathrm{Al}, \mathrm{Cr}, \mathrm{Mg}$ content, the formation of which occurs under conditions of one-sided compression $[10,11]$.

The topic of this study is the chemical zoning of spinels from ores of the aluminous and medium chromium types of the Voikaro-Syninsky massif. The compositions of the ore-forming spinels of the Voikaro-Syninsky massif were studied by A.B. Makeev and co-authors [12, 13]; they are covered in the geological reports of I. S. Chashchukhin, V. Yu. Alimov, N. V. Vakhrusheva; A. B. Makeev; B. V. Pechenkin, and V. G. Kotelnikov.

In his monographs A.B. Makeev presents the results of a study of the mineralogy of ultramafic rocks of the Polar Urals. The chemical compositions of ore-forming chrome spinels of the Syum-Keu, Rai-Iz and Voikaro-Syninsky massifs have been characterized. It is noted that spinels have either a homogeneous internal structure, or zonal, with a later rim of ferrichromite and magnetite $[12,13]$. 
In their report I. S. Chashchukhin, V. Yu. Alimov, N. V. Vakhrusheva [14] discuss the chemical composition of ore-forming spinels of most of the main ore occurrences in the northern part of the Voikaro-Syninsky massif. The zoning of ore bodies by the chemical composition of ore-forming chromium spinel, in particular, body 3415 of the Arkashorskoe ore occurrence, has been studied. A microprobe study of the distribution of chemical components inside grains of accessory chromium spinels during metamorphism has been carried out. It was found that metamorphism leads to the formation of magnetite and chromomagnetite rims in the studied spinels. Rims are formed both by the overgrowth of spinel grains with magnetite and as a result of changes in the chemical composition of its marginal part during retrograde metamorphism.

Features of the geological structure of the studied ore occurrences

In this paper, alumina chromitites of ore body no. 118 of the Yambotyvisskaya area and medium-chromium chromitites of ore body no. 3415 of the Arkashorskoe ore occurrence have been studied.

Ore body no. 118 is located at the watershed of the Levaya Payera River and the Yambotyvis stream. It lies in the rocks of the dunite-harzburgite complex with a dunite content of $10-30 \%$. Harzburgites underwent non-equilibrium metamorphism, as a result of which an aggregate of talc and amphibole developed along enstatite. Chromitites are surrounded by a dunite rim, the thickness of which varies from $0.1 \mathrm{~m}$ to a few meters. The ore body is column-shaped. Its apparent thickness is 8-9 m, its length is $12-13 \mathrm{~m}$. The central part of the ore body is solid, with areas of densely disseminated, medium-grained chromitites.
Ore body no. 3415 exposed in the wall of the left side of the valley Arkashore stream. Ores occur in meta-ultramafic amphibole-olivine-antigorite rocks. Chromitites are surrounded by a dunite rim, the thickness of which ranges from 0.5 to $1.5 \mathrm{~m}$. The length of the ore body is $40 \mathrm{~m}$, with a maximum outlet width of $12 \mathrm{~m}$; the shape is lenticular with complexly oriented contacts. The ore body plunges westward at an angle of $50-80^{\circ}$. The ores are mainly represented by moderately disseminated varieties with separate lenticular and spotty areas, composed of coarse-grained densely disseminated chromitite with serpentine-olivine cement. At the endocontacts, the density of dissemination of ore-forming spinel decreases.

According to the chemical composition of the ore-forming spinel, two blocks are distinguished within the ore body - western and eastern, which have similar thicknesses. Ore-forming chrome spinels of the western block contain on average $\mathrm{Cr}_{2} \mathrm{O}_{3}-46-49$ wt.\%; $\mathrm{Al}_{2} \mathrm{O}_{3}-$ 14-18 wt.\%; $\mathrm{MgO}-13-14$ wt.\%. The chemical composition of the spinels of the eastern block of the ore body is characterized by a higher content of $\mathrm{Cr}_{2} \mathrm{O}_{3}-54-58$ wt.\% and lower $\mathrm{Al}_{2} \mathrm{O}_{3}-6-13$ wt. $\%$ and $\mathrm{MgO}^{2}-8-12$ wt.\%. It should be noted that the composition of the ore-forming spinels of the ore body was determined by the method of wet chemical analysis and reflects the composition of the grains of the mineral as a whole.

Research results

The study of the chemical composition and zoning of mineral grains in this work was carried out using microprobe analysis (Zavaritsky Institute of Geology and Geochemistry of the Ural Branch of the Russian Academy of Sciences, Cameca SX-100, the analysts are I. A. Danilenko,
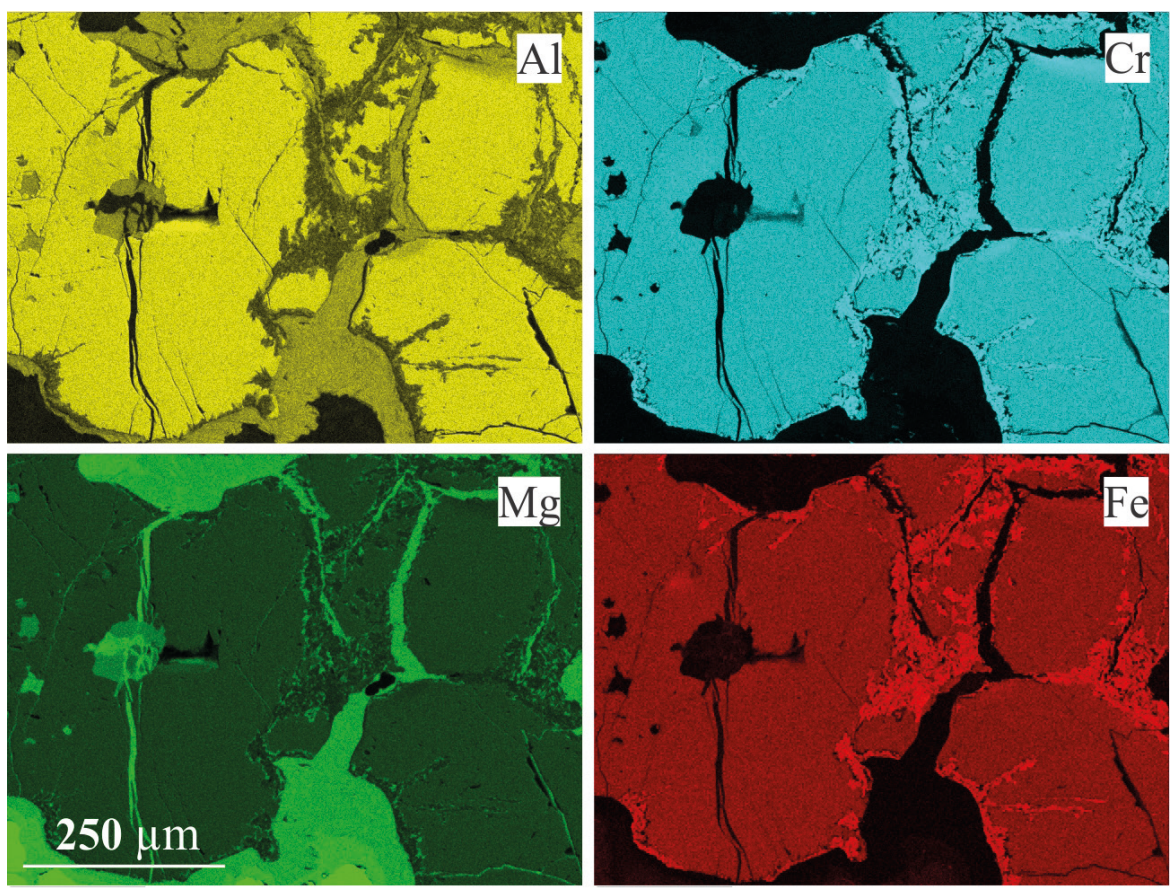

Figure 1. Distribution of chemical elements in grains of ore-forming chrome spinels from ore body no. 118 of the Yambotyvisskaya area. The image was obtained using a scanning electron microscope

Рисунок 1. Распределение химических элементов в зернах рудообразующих хромовых шпинелей из рудного тела № 118 Ямботывисской площади. Изображение получено при помощи сканирующего электронного микроскопа 

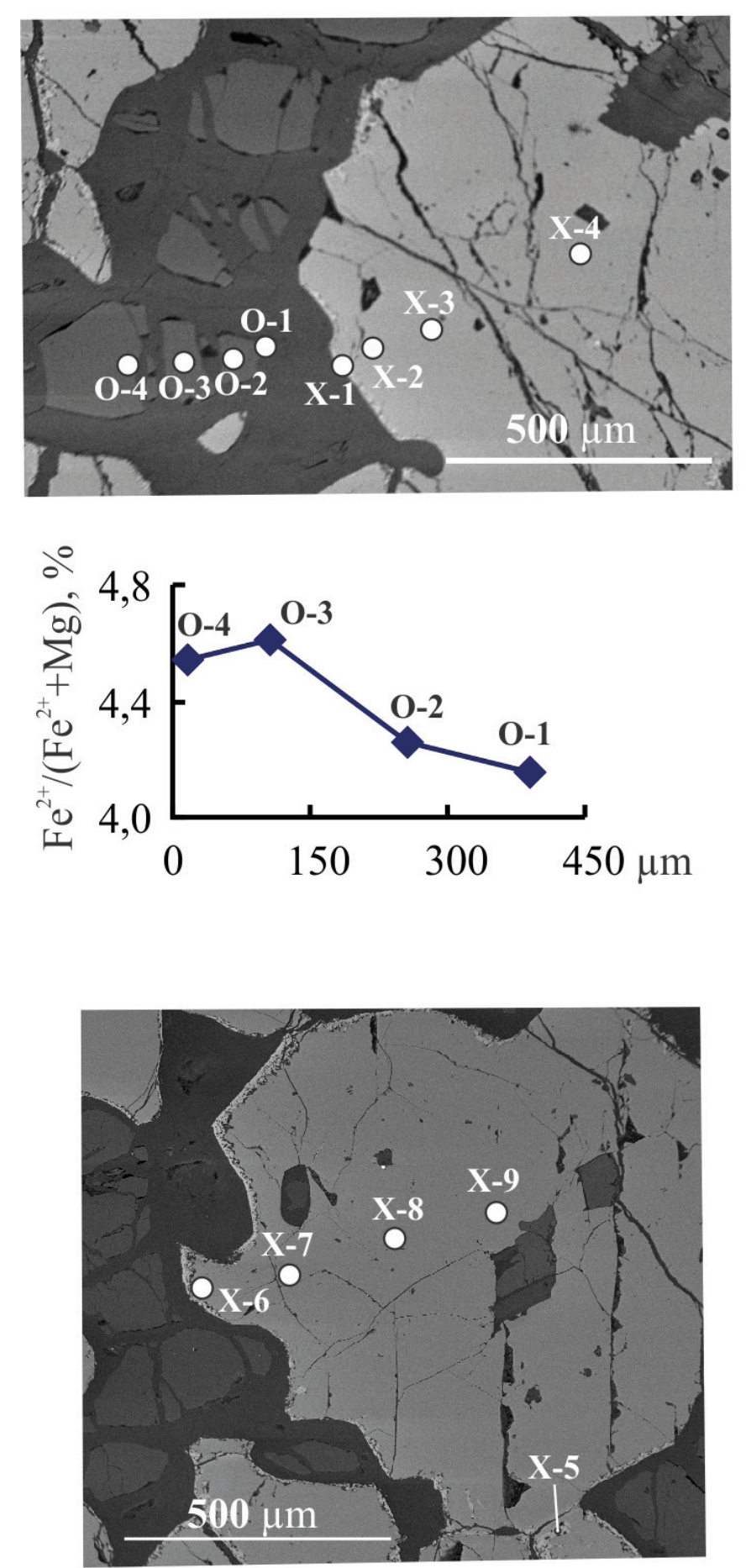
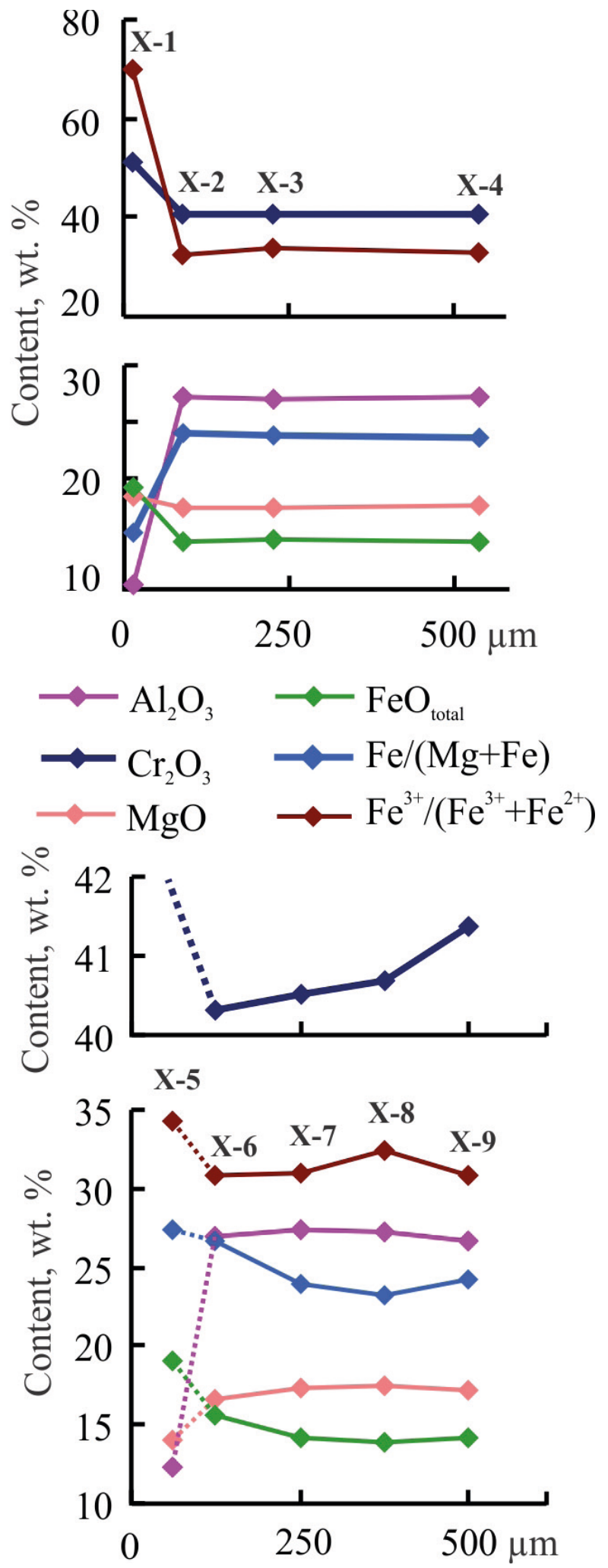

Figure 2. Compositional variations in grains of ore-forming spinel and contacting olivine from sample no. X-1507/8 (ore body no. 118, Yambotyvisskaya area)

Рисунок 2. Вариации содержаний химических элементов в зернах рудообразующей шпинели и контактирующего с ней оливина из обр. X-1507/8 (рудное тело № 118, Ямботывисская площадь)

D. A. Zamyatin) and using a scanning electron microscope (Zavaritsky Institute of Geology and Geochemistry of the Ural Branch of the Russian Academy of Sciences, Jeol JSM-6390LV with an energy dispersive prefix INCA Energy 450 X-Max 80, the analyst is L. V. Leonova).
Spinel grains of ore body no. 118 are surrounded by a border having an average thickness of 1-10 microns, which in some cases reaches 100-150 microns. The boundary between the rim and the core of the grain is sharp; directly at the contact, silicate microinclusions 


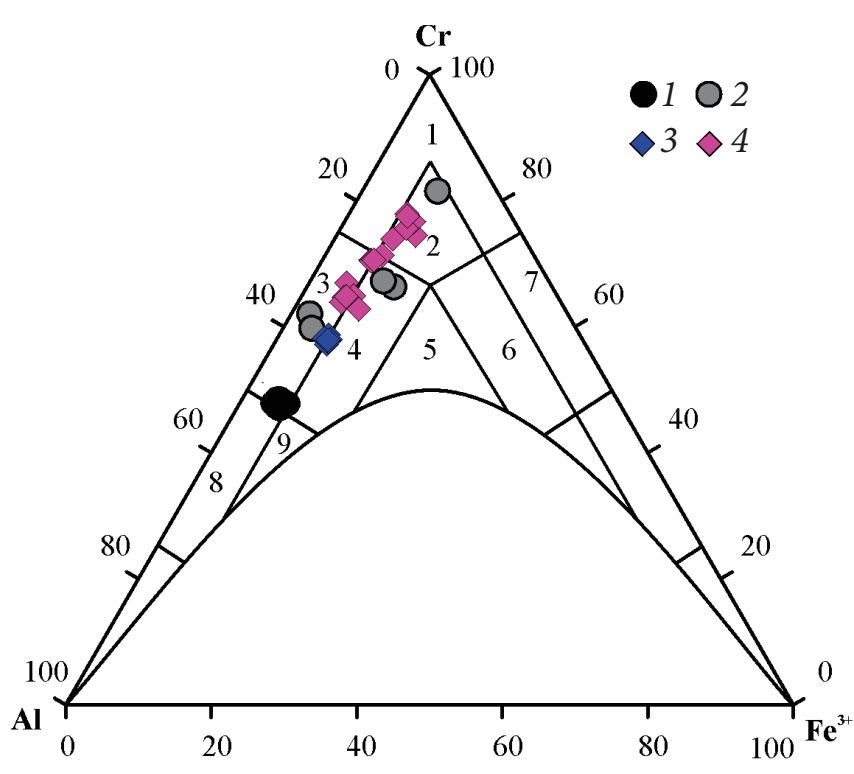

Figure 3. Ratio of trivalent cations in the centers and edges of grains of ore-forming chromium spinels of the Voikaro-Syninsky massif. Yambotyvisskaya area: 1 - core, 2 - rim; Arkashorskoye ore occurrence: 3 - core, 4 - rim

Fields of compositions according to the classification by N. V. Pavlov: 1 - chromite; 2 - subferrichromite; 3 - alumochromite; 4 -subferrialumochromite; 5 - ferrialumochomite; 6 - subalumoferrichromite; 7 - ferrichromite; 8 - chrompicotite; 9 - subferrichrompicotite Рисунок 3. Соотношение трехвалентных катионов в центрах и краях зерен рудообразующих хромовых шпинелей Войкаро-Сыньинского массива. Ямботывисская площадь: 1 - центр, 2 - кайма; Аркашорское рудопроявление: 3 - центр, 4 - кайма

Поля составов по классификации Н. В. Павлова: 1 - хромит; 2-субферрихромит; 3-алюмохромит; 4-субферриалюмохромит; 5 - ферриалюмохромит; 6 - субалюмофреррихромит; 7 - феррихромит; 8 - хромпикотит; 9 - субферрихромпикотит

are concentrated. Rim spinel is lighter in color both in reflected light and in backscattered electrons. It can be seen that the border consists of individual grains ranging in size from 5-10 microns to 50 microns, associated with chlorite flakes, the size of which is $5-10$ microns. Chrome spinel, similar in chemical composition and reflectivity to the spinel, is developed along grain boundaries and around cracks and inside deformation zones (fig. 1). This indicates that the rims develop by replacing grains of chromium spinel, and not growing on them.

In the cores of spinel grains of ore body no. 118 of the Yambotyvisskaya area from the center towards the rim, a slight (from 41 to $40 \mathrm{wt} . \%$ on average) decrease in the content of $\mathrm{Cr}_{2} \mathrm{O}_{3}$, as well as $\mathrm{MgO}$ from 17-17.5 wt.\% is observed up to $16-16.5$ wt.\% (points X-2-X-4 and $\mathrm{X}-6-\mathrm{X}-9$ in fig. 2). At the same time, towards the border, the iron content of the mineral increases from $23-24 \%$ to $26 \%$, i. e. by $2-3 \%$ (in ore-forming spinels of the Rai-Iz massif, the iron content increases towards the edge of the grain by $5-10 \%$ [11]). The content of $\mathrm{Al}_{2} \mathrm{O}_{3}$ in the grain cores varies between $26-27 \mathrm{wt} . \%, \mathrm{FeO}-13-14 \mathrm{wt} . \%$.

Spinel, forming replacement rims, is characterized by an increased content of $\mathrm{Cr}_{2} \mathrm{O}_{3}-51-52$ wt.\% and $\mathrm{FeO}-20-21$ wt.\% and additionally reduced $\mathrm{Al}_{2} \mathrm{O}_{3}-$ 9-12 wt.\% and $\mathrm{MgO}-12-14$ wt.\%. The oxidation state of iron varies widely from 13 to $70 \%$, on average taking values in the range from $35-40 \%$. Spinels with the highest $\mathrm{Fe}^{3+} /\left(\mathrm{Fe}^{3+}+\mathrm{Fe}^{2+}\right)$ ratio are found in the edge part of the rim, at the contact with silicates, and with the lowest one, in the inner parts of grains, in recrystallization zones. In the oxidized spinels of the rim, an increase in the $\mathrm{FeO}_{\text {total }}$ content occurs due to the enrichment of the mineral with trivalent iron (fig. 2, point X-1). As can be seen on the maps of the distribution of chemical elements in spinel grains, the border between the rim and the core of the grain is sharp (fig. 1). The rim is well enriched in $\mathrm{Cr}$ and $\mathrm{Fe}$ and depleted in $\mathrm{Mg}$ and $\mathrm{Al}$. That is, the composition of the mineral corresponds to the ore-forming spinels of medium-chromium chromitites of the Voikaro-Syninsky massif, although in most analyses it has an increased degree of iron oxidation by $10-15 \%$ (fig. 3). Thus, in the ores of ore occurrence 118, the development of mediumchromium, ferruginous chromium spinels over alumina ones is observed.

The iron content of olivine $\left(\mathrm{Fe}^{2+} /\left(\mathrm{Fe}^{2+}+\mathrm{Mg}\right)\right)$ decreases from the centre of the grain to the edge by $0.5-1 \%$, while the content of $\mathrm{Cr}_{2} \mathrm{O}_{3}$ in the mineral is less than 0.02 wt.\%, that is, below the detection limit in the study by microprobe analysis.

Around the spinel grains composing ore body 3415, a rim is also developed, the thickness of which is up to $100-300 \mu \mathrm{m}$ on average. The border is composed of lighter spinel in reflected light, as well as chlorite, which forms regularly oriented inclusions, due to which the border acquires a structure similar to a graphic one. The chlorite content in the border is $7-10 \%$, the grain size of the mineral is on average $10-30$ microns. The smallest thickness of the rim is characteristic for the chrome spinels of the western block of the ore body, the highest - for the spinels of the eastern block, where there are mineral grains completely replaced by a chlorite-spinel aggregate.

The content of $\mathrm{Cr}_{2} \mathrm{O}_{3}$ in spinel cores varies between 47-48 wt.\%; $\mathrm{Al}_{2} \mathrm{O}_{3}=18-19$ wt.\%; $\mathrm{FeO}=18-20$ wt.\% ; $\mathrm{MgO}=13-15$ wt.\%; $\mathrm{Fe}^{3+} /\left(\mathrm{Fe}^{3+}+\mathrm{Fe}^{2+}\right)=28-30 \%$. In a rim composed of a spinel-chlorite aggregate, the content of $\mathrm{Cr}_{2} \mathrm{O}_{3}$ increases to $51-55$ wt. $\%$, and $\mathrm{FeO}=$ up to 21-25 wt.\%. This reduces the of $\mathrm{Al}_{2} \mathrm{O}_{3}$ content to $7-14$ wt.\% and $\mathrm{MgO}$ up to 9-11 wt.\%. The oxidation state of iron in the spinel of the rim is lower than in the core and averages $22-24 \%$ (fig. 3, 4). In some cases, at the contact with the silicate part of chromitite in spinel, increased (up to 30-35\%) values of $\mathrm{Fe}^{3+} /\left(\mathrm{Fe}^{3+}+\mathrm{Fe}^{2+}\right)$ are observed.

The maps of the element distribution (fig. 5) show that the decrease in the $\mathrm{Al}$ content towards the grain edge is well expressed, compared with the change in the $\mathrm{Cr}$, Fe, and $\mathrm{Mg}$ contents. In the rim, angular blocks with different amounts of $\mathrm{Al}$ are distinguished. The rim is unevenly developed along the periphery of the grains.

In olivine grains from the silicate part of chromitites of ore body no. 3415, the iron content gradually decreases towards the contact with the ore-forming chromium spinel from $5.5-5.7 \%$ in the core of the grain to $5-5.2 \%$ in the rim. The content of $\mathrm{Cr}_{2} \mathrm{O}_{3}$ in the rims of the mineral grains reaches $0.2 \mathrm{wt} . \%$ (the detection limit of the element is lower $-0.02 \mathrm{wt} . \%$ ). 

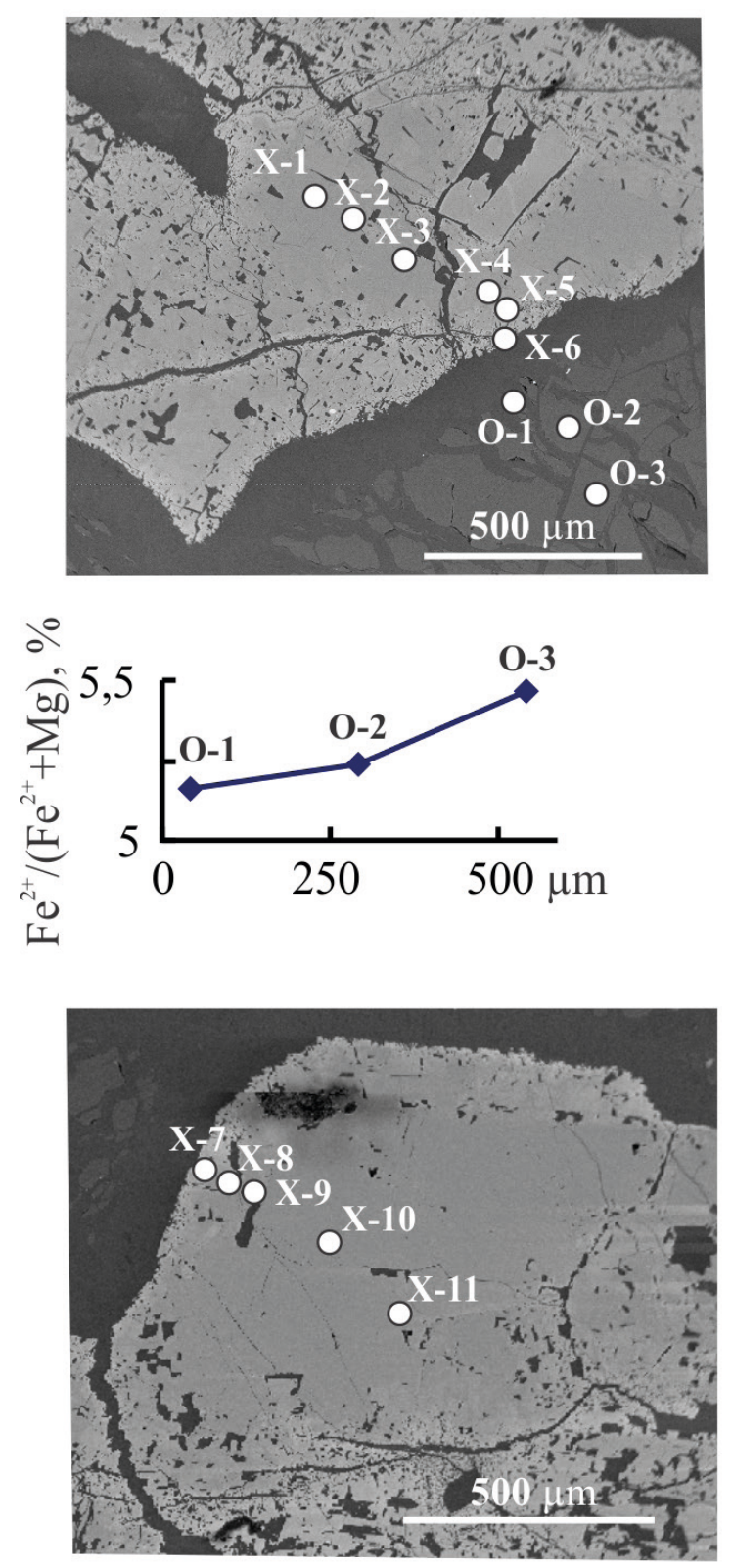
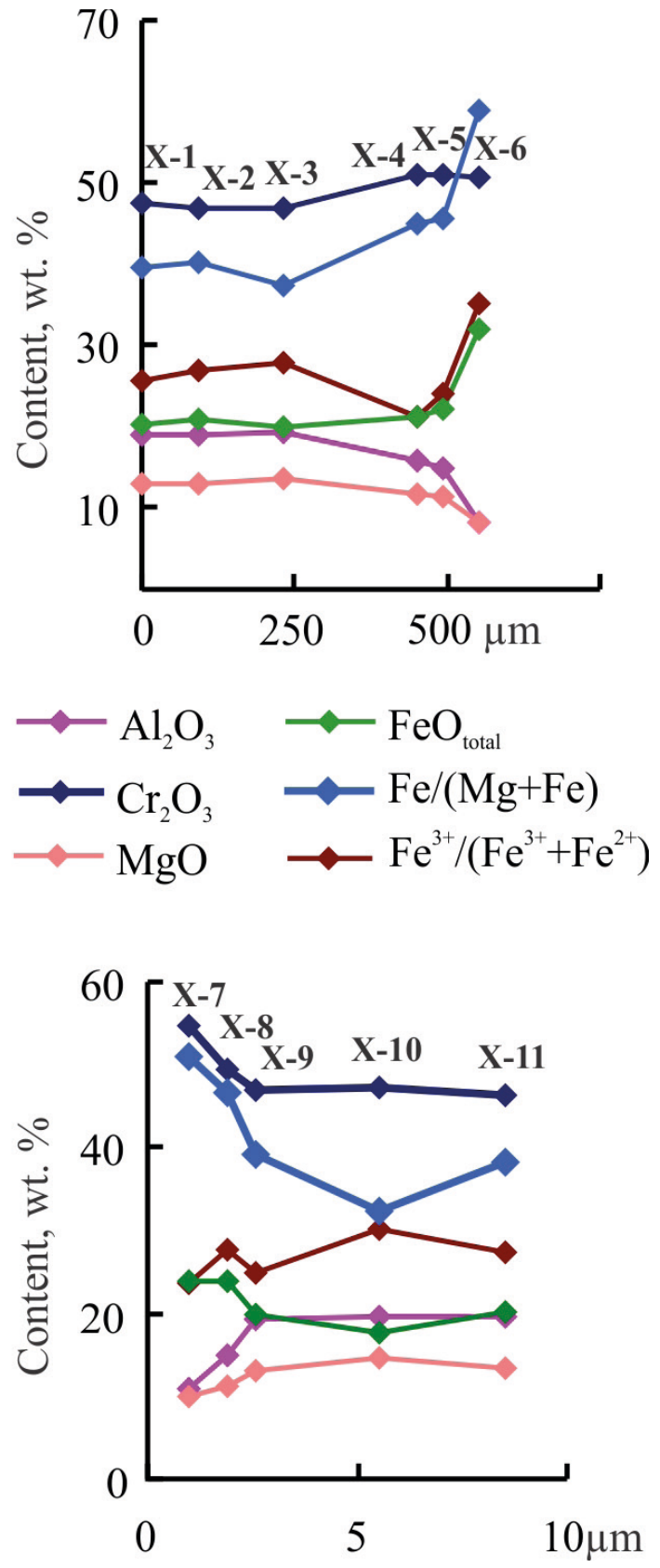

Figure 4. Compositional variation in the grain of ore-forming spinel and olivine from sample no. 3701 (ore body no. 3415, Arkashorskoye ore occurrence)

Рисунок 4. Вариации содержаний химических элементов в зерне рудообразующей шпинели и контактирующего с ней оливина из обр. 3701 (рудное тело № 3415, Аркашорское рудопроявление)

Using an Ballhaus-Berry-Green olivine-spinel geothermometer and a oxybarometer [15], the temperature of olivine-spinel equilibrium and oxygen fugacity were estimated at which the zoning of ore-forming spinels of the studied ore bodies was formed. The temperatures values calculated on the basis of the compositions of the spinel cores from the chromium ore of the Yambotyvisskaya ore occurrence are $760 \pm 20^{\circ} \mathrm{C}$, the oxygen fugacity values are 1.9-2.1 units above the FMQ buffer. The temperature of the olivine-spinel equilibrium in the rim also corresponds to the indicated range but the oxygen fugacity is higher: $+3 \ldots+3.2 \log$ units relative to the FMQ buffer. In areas of the border with a low oxidation state of iron $\left(\mathrm{Fe}^{3+} /\left(\mathrm{Fe}^{3+}+\mathrm{Fe}^{2+}\right)=13 \%\right)$ the value of $\mathrm{fO}_{2}=0.7$ log units above the FMQ buffer. The scatter in the values of oxygen fugacity and the degree of iron oxidation in the grain rims of ore-forming spinels in the Yambotyvisskaya area indicates that the conditions for the formation of these rims were nonequilibrium.

In the studied chromitite of the Arkashorskoye ore occurrence, the temperature of the olivine-spinel equilibrium is $650 \pm 20^{\circ} \mathrm{C}$, the oxygen fugacity varies within $+2 \ldots+2.3 \log$ units relative to the FMQ buffer. From the grain core to its rim, the oxygen fugacity increases by $0.1-0.2 \mathrm{log}$ units, and the temperature of the olivinespinel equilibrium decreases by $40{ }^{\circ} \mathrm{C}$, which is lower than the error of the oxybarometer and geothermometer. It follows from this that the formation of the zoning of 

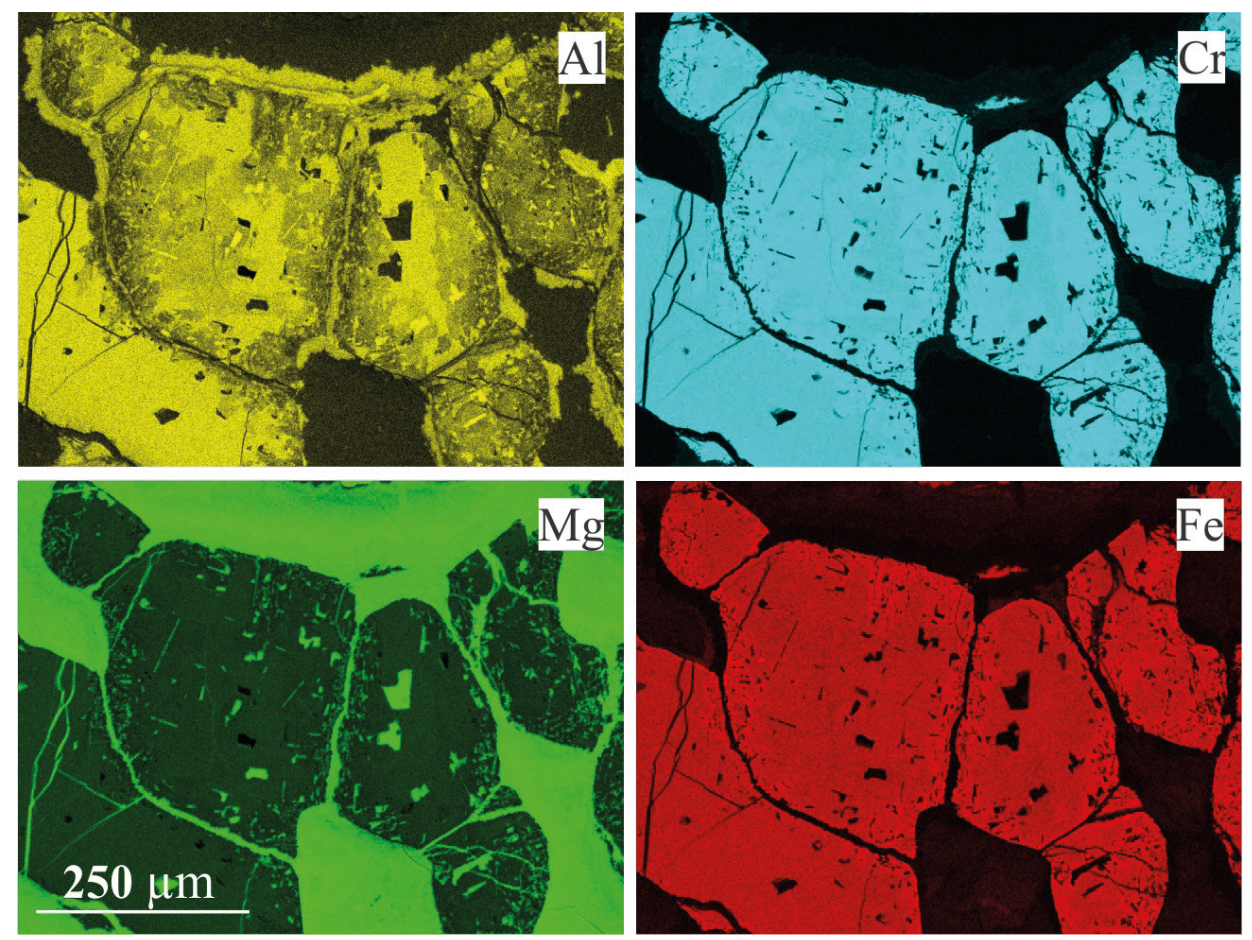

Figure 5. Distribution of chemical elements in grains of ore-forming chromium spinels of ore body no. 3415 of the Arkashorskoye ore occurrence. The image was obtained using a scanning electron microscope

Рисунок 5. Распределение химических элементов в зернах рудообразующих хромовых шпинелей рудного тела № 3415 Аркашорского рудопроявления. Изображение получено при помощи сканирующего электронного микроскопа

the ore-forming spinels of the Arkashorskoye ore occurrence took place at relatively constant $\mathrm{T}-\mathrm{fO}_{2}$ parameters.

Discussion of the results

The ratios of the compositions of the cores and rims of grains of ore-forming spinels of the considered objects are close to the compositions of zonal spinels of the Golyamo Kamenyane massif studied in [4]. Researchers have found that the formation of a replacement rim for high-chromium, and relatively ferrous spinels for medium-chromium, is associated with regressive water metamorphism that took place under reducing conditions [4]. Later, the zoned spinels of the Golyamo Kamenyane massif were studied by the EBSD method. It was found that the rim is composed of an aggregate of chrome spinel grains [7]. The analysis of their orientation made it possible to determine that the formation of a rim occurs as a result of dynamic recrystallization of spinel. The authors conclude that spinels have undergone metamorphism in the shear deformation zone under mid-crustal conditions [7].

Ore body 3415 of the Arkashorkoye ore occurrence consists of two blocks, the spinels of which differ in composition. The ore-forming mineral has zoning manifested in the development of a rim of recrystallization of more chromium spinel around less chromium. The chemical zoning of the ore body is due to the fact that the degree of recrystallization of the mineral increases from west to east, up to the complete replacement of grains with a chromite-chlorite aggregate. In the ores of the eastern part of the ore body, the development of such rims is significant, up to the complete replacement of the mineral. Due to the fact that the compositions of the chromium spinel of the ore body were determined by the method of wet chemistry in monomineral fractions, the effect of changing the chemical composition with an increase in the degree of recrystallization of the mineral is clearly expressed. At the same time, ore body 3415 lies in a petrographically homogeneous section, composed of amphibole-olivine-antigorite rocks. In the case of ore metamorphism together with the host rocks, the ores should have been completely recrystallized, or symmetrical zoning would have formed. It follows that the zoning of ore body 3415 and an increase in the chromium content of newly formed spinels occurred under the action of a directed (one-sided) stress effect on the ore body. The results of oxythermobarometry of chromium ores allow us to conclude that the transformations of chromitites took place in subcrustal conditions at constant $\mathrm{T}-\mathrm{fO}$ parameters. The grain rims consist of blocks with different compositions, primarily aluminum content. This may be a consequence of the dynamic recrystallization of spinel.

In the chromitites of the Yambotyvisskaya area, the increase in the chromium content of the ore-forming spinel from the core to the rim of the grain occurs under nonequilibrium conditions. As a result, spinel microblocks are present in the rim, both with an increased content of ferric iron and with a normal one, typical of ore-forming spinels of the Yambotyvisskaya area. The composition of the grain rim of the ore-forming spinel of the Yambotyvisskaya area in some areas becomes close to that of the central parts of spinel grains of medium-chromium ores of the Arkashorskoye ore occurrence. 
The study of the zoning of ore-forming chromium spinels allows us to conclude that metamorphic transformations of alumina and medium-chromium chromitites occurring in crustal conditions under the action of directional stress at relatively constant $\mathrm{T}-\mathrm{fO}_{2}$ parameters lead to an increase in the chromium content of the ore mineral.

The research was carried out with the financial support of the Russian Foundation for Basic Research (project no. 18-05-70016).

\section{REFERENCES}

1. Puchkov V. N., Steinberg D. S. 1990, Structure, evolution, and minerageny of the Rai-Iz hyperbasite massif. Sverdlovsk, 228 p. (In Russ.) 2. Bliss N. W., MacLean W. H. 1975, The paragenesis of zoned chromite from central Manitoba. Geochimica et Cosmochimica Acta, vol. 39, issues 6-7, pp. 973-990. https://doi.org/10.1016/0016-7037(75)90042-3

3. Evans B. W., Frost B. R. 1975, Chrome-spinel in progressive metamorphism - a preliminary analysis. Geochimica et Cosmochimica Acta, vol. 39, issues 6-7, pp. 959-972. https://doi.org/10.1016/0016-7037(75)90041-1

4. Gervilla F., Padrón-Navarta J. A., Kerestedjian T., Sergeeva I., González-Jiménez J. M., Fanlo I. 2012, Formation of ferrian chromite in podiform chromitites from the Golyamo Kamenyane serpentinite, Eastern Rhodopes, SE Bulgaria: a two-stage process. Contrib. Mineral Petrol., vol. 164, pp. 643-657. https://doi.org/10.1007/s00410-012-0763-3

5. González-Jiménez J., Kerestedjian T., Proenza J., Gervilla F. 2009, Metamorphism on Chromite Ores from the Dobromirtsi Ultramafic Massif, Rhodope Mountains (SE Bulgaria). Geologica Acta, vol. 7, pp. 413-429. https://doi.org/10.1344/104.000001447

6. Ozawa K. 1989, Stress-induced Al-Cr zoning of spinel in deformed peridotites. Nature, vol. 338, pp. 141-144. https://doi.org/10.1038/338141a0

7. Satsukawa T., Piazolo S., González-Jiménez J. M., Colás V., Griffin W. L., O'Reilly S. Y., Gervilla F., Fanlo I., Kerestedjian Th. N. 2015, Fluid-present deformation AIDS chemical modification of chromite: Insights from chromites from Golyamo Kamenyane, SE Bulgaria. Lithos, vol. 228-229, pp. 78-89. https://doi.org/10.1016/j.lithos.2015.04.020

8. Lehmann J. 1983, Diffusion between olivine and spinel: application to geothermometry. Earth Planet. Sci. Lett., vol. 64, issue 1, pp. 123-138. https://doi.org/10.1016/0012-821X(83)90057-2

9. Ozawa K. 1984, Olivine-spinel geospeedometry: Analysis of diffusion-controlled Mg-Fe ${ }^{2+}$ exchange. Geochimica et Cosmochimica Acta, vol. 48, issue 12, pp. 2597-2611. https://doi.org/10.1016/0016-7037(84)90308-9

10. Vakhrusheva N. V., Shiryaev P. B., Stepanov A. E., Bogdanova A. R. 2017, Petrology and chromite-bearing of the ultramafic Rai-Iz massif (Polar Urals). Ekaterinburg, 265 p. (In Russ.)

11. Shiryaev P. B., Vakhrusheva N. V. 2017, Chemical zoning of spinels and olivines from chromitites and the enclosing ultramafites of the Rai-Iz massif Tsentralnoye deposit (the Polar Urals). News of the Ural State Mining University. Issue 4 (48), pp. 29-35. http://dx.doi.org/10.21440/23072091-2017-4-29-35

12. Makeev A. B., Perevozchikov B. V., Afanasyev A. K. 1985, Chromite content of the Polar Urals. Syktyvkar, 152 p. (In Russ.)

13. Makeev A. B., Bryanchaninova N. I. 1999, Topomineralogy of ultrabasic rocks of the Polar Urals. St. Petersburg, 252 p. (In Russ.)

14. Chashchukhin I. S., Alimov V. Yu., Vakhrusheva N. V. 1984, Report on research work called "Features of the material composition of chromites and the formation of hyperbasites in the northern part of the Voikaro-Syninsky hyperbasite massif". In 5 books. Sverdlovsk. (In Russ.)

15. Ballhaus C., Berry R. F., Green D. H. 1991, High pressure experimental calibration of the olivine-orthopyroxene-spinel oxygen barometer: implication for the oxidation state of the upper mantle. Contrib. Miner. Petrol., vol. 107, pp. 27-40. https://doi.org/10.1007/BF00311183 


\title{
Зонаиьность рудообразуюших хромовых шпинелей среднехромистых и глиноземистых хромовых руд Войкаро-Сыньинского массива
}

\author{
Павел Борисович ШИРЯЕВ ${ }^{1,2 *}$ \\ Надежда Владимировна ВАХРУШЕВА ${ }^{1,2 * *}$ \\ ${ }^{1}$ Институт геологии и геохимии им. А. Н. Заварицкого УрО РАН, Екатеринбург, Россия \\ Уральский государственный горный университет, Екатеринбург, Россия
}

Аннотация

Актуальность работы. Условия образования хромовых руд в альпинотипных гипербазитах остаются актуальным предметом исследований. В научных работах последних лет стало уделяться внимание вопросу изменения химического состава рудообразующих минералов и хромовых руд под действием процессов деформации и динамической рекристаллизации, сопровождающих метаморфизм. Результаты таких исследований позволяют сформулировать новую модель образования хромового оруденения, учитывающую значительный объем геологических данных, указывающих на то, что альпинотипные ультрамафиты являются «мантийными тектонитами». В нашей работе изучены зональные рудообразующие шпинели из хромовых руд Полярного Урала. Результаты исследования позволяют связать образование химической зональности в минералах и рудных телах с рекристаллизацией под действием стрессовых напряжений.

Цель работь - исследование условий образования химической зональности хромовых шпинелей из глиноземистых и среднехромистых хромовых руд Войкаро-Сыньинского массива.

Результаты. Изучены зональные рудообразующие шпинели из среднехромистых и глиноземистых хромовых руд Войкаро-Сыньинского массива (Полярный Урал). Установлено, что по зернам рудообразующих шпинелей развиты каймы замещения с повышенным по отношению к ядру содержанием Сr $\mathrm{O}_{3}$ и степенью окисления железа, а также пониженным содержанием $\mathrm{Al}_{2} \mathrm{O}_{3}$. Степень окисления железа в каймах большинства зерен не превышает значений, типичных для неизмененных рудообразующих шпинелидов. Методами окситермобарометрии определены $\mathrm{T}-\mathrm{fO}_{2}$-параметры образования зональности в шпинелидах. Произведено сравнение с зональными хромовыми шпинелями массива Голямо-Каменяне (Болгария).

Вывод. Метаморфические преобразования глиноземистых и среднехромистых хромититов ВойкароСыньинского массива, происходящие в субкоровых условиях под действием направленного стресса при относительно постоянных $\mathrm{T}-\mathrm{fO}_{2}$-параметрах, приводят к увеличению хромистости рудного минерала.

Ключевые слова: Полярный Урал, хромовые руды, химическая зональность, динамическая кристаллизация, стрессовые напряжения.

Исследования проведены при финансовой поддержке РФФИ (проект № 18-05-70016).

\section{ЛИТЕРАТУРА}

1. Строение, эволюция и минерагения гипербазитового массива Рай-Из / под ред. В. Н. Пучкова и Д. С. Штейнберга. Свердловск: УрО AH CCCP, 1990. 228 C.

2. Bliss N. W., MacLean W. H. The paragenesis of zoned chromite from central Manitoba // Geochimica et Cosmochimica Acta. 1975. Vol. 39. Issues 6-7. P. 973-990. https://doi.org/10.1016/0016-7037(75)90042-3

3. Evans B. W., Frost B. R. Chrome-spinel in progressive metamorphism - a preliminary analysis // Geochimica et Cosmochimica Acta. 1975. Vol. 39. Issues 6-7. P. 959-972. https://doi.org/10.1016/0016-7037(75)90041-1

4. Gervilla F., Padrón-Navarta J. A., Kerestedjian T., Sergeeva I., González-Jiménez J. M., Fanlo I. Formation of ferrian chromite in podiform chromitites from the Golyamo Kamenyane serpentinite, Eastern Rhodopes, SE Bulgaria: a two-stage process // Contrib. Mineral Petrol. 2012. Vol. 164. P. 643-657. https://doi.org/10.1007/s00410-012-0763-3

5. González-Jiménez J., Kerestedjian T., Proenza J., Gervilla F. Metamorphism on Chromite Ores from the Dobromirtsi Ultramafic Massif, Rhodope Mountains (SE Bulgaria) // Geologica Acta. 2009. Vol. 7. P. 413-429. https://doi.org/10.1344/104.000001447

6. Ozawa K. Stress-induced Al-Cr zoning of spinel in deformed peridotites // Nature. 1989. Vol. 338. P. 141-144. https://doi.org/10.1038/338141a0 7. Satsukawa T., Piazolo S., González-Jiménez J. M., Colás V., Griffin W. L., O'Reilly S. Y., Gervilla F., Fanlo I., Kerestedjian Th. N. Fluid-present deformation AIDS chemical modification of chromite: insights from chromites from Golyamo Kamenyane, SE Bulgaria // Lithos. 2015. Vol. 228-229. P. 78-89. https://doi.org/10.1016/j.lithos.2015.04.020

8. Lehmann J. Diffusion between olivine and spinel: application to geothermometry // Earth Planet. Sci. Lett. 1983. Vol. 64. Issue 1. P. 123-138. https://doi.org/10.1016/0012-821X(83)90057-2

9. Ozawa K. Olivine-spinel geospeedometry: Analysis of diffusion-controlled Mg-Fe ${ }^{2+}$ exchange // Geochimica et Cosmochimica Acta. 1984. Vol. 48. Issue 12. P. 2597-2611. https://doi.org/10.1016/0016-7037(84)90308-9 
10. Вахрушева Н. В., Ширяев П. Б., Степанов А. Е., Богданова А. Р. Петрология и хромитоносность ультраосновного массива Рай-Из (Полярный Урал). Екатеринбург: ИГГ УрО РАН, 2017. 265 с.

11. Shiryaev P. B., Vakhrusheva N. V. Chemical zoning of spinels and olivines from chromitites and the enclosing ultramafites of the Rai-Iz massif Tsentralnoye deposit (the Polar Urals) // Известия УГГУ. 2017. Вып. 4 (48). С. 29-35. http://dx.doi.org/10.21440/2307-2091-2017-4-29-35

12. Макеев А. Б., Перевозчиков Б. В., Афанасьев А. К. Хромитоносность Полярного Урала. Сыктывкар: Коми фил. АН СССР, 1985.152 с.

13. Макеев А. Б., Брянчанинова Н. И. Топоминералогия ультрабазитов Полярного Урала. СПб: Наука, 1999. 252 с.

14. Чащухин И. С., Алимов В. Ю., Вахрушева Н. В. Особенности вещественного состава хромитов и вопросы формирования гипербазитов северной части Войкаро-Сыньинского гипербазитового массива: отчет о НИР. В 5 кн. Свердловск, 1984.

15. Ballhaus C., Berry R. F., Green D. H. High pressure experimental calibration of the olivine-orthopyroxene-spinel oxygen barometer: implication for the oxidation state of the upper mantle // Contrib. Miner. Petrol., 1991. Vol. 107. P. 27-40. https://doi.org/10.1007/BF00311183 